\title{
Analysis of Battery Management Algorithms on DC Microgrids
}

\author{
Vendi A. Nugroho ${ }^{1 *)}$, Awang N.I. Wardana ${ }^{2)}$, and Dwi Joko Suroso ${ }^{3)}$ \\ 1,2,3) Departement of Nuclear Engineering and Engineering Physics, Universitas Gadjah Mada, Indonesia \\ Corresponding Email: *) vendi.ardianto.n@mail.ugm.ac.id
}

\begin{abstract}
Management of battery at direct current (DC) microgrids is the essential factor to maintain the balance of power and the bus voltage's stability in the grids. To ensure the quality of battery management is necessary to simulate the operation of the battery management system. This paper presents the simulations in various battery management algorithms. The simulations were designed to determine the effect of these variations on the balance of the power balance, bus voltage stability, and battery consumption level. The configurations of one, two, and three battery groups could maintain a balance of power balance. The three arrangements could ensure the bus voltage stability at a value of 24 Volts. The variations in the battery group configurations cause different battery consumption levels. The three-battery group configuration has a lower power consumption rate of $0.1 \%$ than other battery group configurations. Variations in the battery management algorithms affect power balance, bus voltage stability, and battery electricity consumption. The result showed the best power balance achieved by an algorithm without counting a value-based state of charge (SoC). The algorithm also committed that the difference between the supply and demand equal to 0 Watts. For the voltage stability, the algorithms that were counting a value-based SoC can maintain bus voltage stability at a value of 24 Volts. Nevertheless, other algorithms that rely on less than one SoC value-based and have the lowest mean value of $\mathrm{SoC}$ reduction are equal to $0.19 \%$.
\end{abstract}

Keywords: Direct current microgrid, energy storage system, and battery management.

\section{Pendahuluan}

Masyarakat seringkali menggunakan peralatan listrik seperti komputer jinjing, telepon, televisi, dan perangkat rumah tangga lainnya yang membutuhkan suplai listrik arus searah menggunakan jaringan listrik skala mikro arus searah [1]. Jaringan listrik skala mikro tersebut adalah jaringan energi lokal yang melibatkan sumber energi terdistribusi dan sistem penyimpanan energi [2]. Konsep jaringan listrik ini dapat menjadi solusi optimal karena efisiensi, biaya, dan keandalannya [3]. Jaringan listrik skala mikro dapat dijalankan dalam dua mode yakni mode terhubung jaringan listrik atau mode mandiri (tidak terhubung jaringan listrik). Keseimbangan neraca daya adalah isu penting pada mode mandiri karena sifat intermiten yang dimiliki oleh sumber energi terbarukan [4]. Baterai menjadi komponen yang berperan penting untuk menjaga kestabilan operasional sistem yang bersifat intermiten [5]. Sumber energi terbarukan seperti panel surya dan baterai terhubung ke bus DC melalui converter DC/DC [6]. Manajemen baterai pada jaringan listrik arus searah skala mikro mode mandiri diperlukan untuk menjaga kestabilan tegangan bus dan keseimbangan daya listrik antara sumber energi dengan beban listrik. Oleh karena itu, algoritma dari manajemen baterai menjadi mempunyai peranan yang cukup penting pada jaringan listrik skala mikro arus searah.

Banyak penelitian yang mencoba untuk mengembangkan algoritma-algoritma manajemen baterai. Jayasena [7] dan Sahoo [8] telah mengembangkan algoritma manajemen baterai berbasis state of charge $(\mathrm{SoC})$ dan tegangan bus pada sistem penyimpanan baterai yang terdiri dari satu baterai. Jing [9] meneliti algoritma manajemen baterai berbasis tegangan bus dan tegangan baterai pada sistem penyimpanan energi yang terdiri dari satu baterai dan satu kapasitor ultra. Das [10] mengembangkan algoritma manajemen baterai berbasis SoC pada sistem penyimpanan energi yang terdiri dari sejumlah baterai. Algoritma manajemen baterai berbasis SoC menjadi tren penelitian dalam rentang tahun 20182020 dan umumnya sistem penyimpanan energi yang diteliti terdiri dari 1 baterai. Algoritma manajemen baterai pada sejumlah baterai masih perlu diselidiki lebih lanjut.

Makalah ini mempresentasikan penelitian yang bertujuan menganalisis algoritma manajemen baterai berbasis state of charge $(\mathrm{SoC})$ pada sistem penyimpan energi yang terdiri dari sejumlah baterai. Variasi konfigurasi baterai dan algoritma manajemen baterai akan disimulasikan pada studi kasus. Pengaruh konfigurasi baterai dan algoritma manajemen baterai dianalisis untuk mengetahui kemampuannya dalam menjaga keseimbangan neraca daya, kestabilan tegangan bus, dan tingkat konsumsi baterai.

Untuk pengujian penelitian dibatasi pada obyek penelitian dan metode pengujian algoritma. Obyek penelitian terbatas pada jaringan listrik arus searah skala mikro mode mandiri yang terdiri dari panel surya, sistem penyimpan energi yang terdiri dari tiga baterai, konverter tipe arus searah, dan beban listrik arus searah. Algoritma manajemen baterai dievaluasi menggunakan metode simulasi jaringan listrik arus searah skala mikro [11].

\section{Metodologi}

Pada penelitian ini, simulasi jaringan listrik arus searah skala mikro dilakukan untuk mengevaluasi 
algoritma manajemen baterai. Alat penelitian terdiri dari perangkat keras dan perangkat lunak. Perangkat keras yang digunakan dalam penelitian ini terangkum pada Tabel 1.

Tabel 1. Daftar perangkat keras

\begin{tabular}{ccc}
\hline No. & Perangkat Keras & Fungsi \\
\hline 1 & $\begin{array}{c}\text { Laptop Acer Aspire E5-471- } \\
\text { 39YT (intel Core i3, RAM } \\
\text { 8GB DDR4) }\end{array}$ & $\begin{array}{c}\text { Menjalankan program } \\
\text { simulasi 4DIAC-IDE, } \\
\text { 4DIAC-RTE, Mosquitto, } \\
\text { dan Python }\end{array}$ \\
\hline 2 & Ponsel Samsung J6 & $\begin{array}{c}\text { Perangkat tambatan } \\
\text { thethering) }\end{array}$ \\
\hline
\end{tabular}

Perangkat lunak yang digunakan dalam penelitian ini terangkum pada Tabel 2. Semua perangkat lunak tersebut dijalankan pada sistem operasi Windows 10. 4DIAC-IDE adalah platform build environtment yang menyediakan lingkungan rekayasa sesuai standar IEC 61499 untuk aplikasi kendali terdistribusi [12]. 4DIAC-RTE merupakan platform runtime environtment IEC 61499 yang menargetkan perangkat kendali tertanam berkapasitas 16-bit atau 32 bit [13].

Tabel 2. Daftar perangkat lunak

\begin{tabular}{ccc}
\hline No. & Perangkat Lunak & Versi \\
\hline 1 & Eclipse 4DIAC-IDE & 1.11 .0 \\
\hline 2 & Eclipse 4DIAC-RTE & 1.11 .0 \\
\hline 3 & Mosquitto & 1.6 .10 \\
\hline 4 & Python & 3.6 \\
\hline
\end{tabular}

Pada penelitian ini, terdapat dataset akan dikirimkan dari laptop ke model terdistribusi berbasis IEC 61499 melalui protokol komunikasi Message Queuing Telemetry Transport (MQTT). Bahasa pemrograman Python digunakan untuk membaca dataset dan mengirimkan data tersebut ke model terdistribusi berbasis IEC 61499. Perangkat lunak Mosquitto digunakan untuk memungkinkan komunikasi data menggunakan protokol MQTT. Komunikasi data dari laptop ke model terdistribusi tersebut dihubungkan melalui mekanisme tambatan yang dinyalakan oleh ponsel. Perangkat lunak 4DIAC-IDE dan 4DIAC-RTE digunakan untuk menjalankan model terdistribusi berbasis IEC 61499.

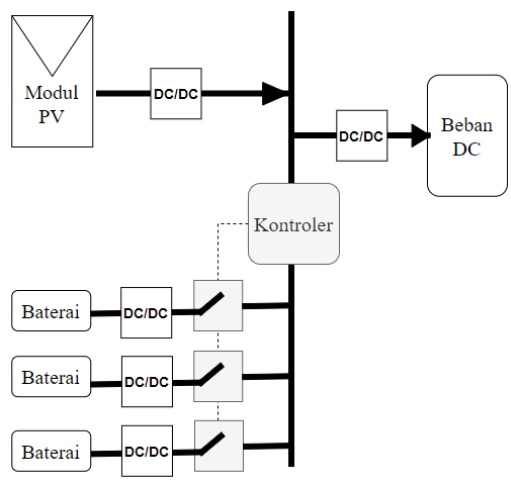

Gambar 1. Model jaringan listrik arus searah skala mikro
Dataset yang dikirimkan ke model terdistribusi adalah dataset beban listrik dan dataset yang mencakup data waktu, iradiansi matahari, dan suhu lingkungan. Data beban listrik dibuat berdasarkan perhitungan studi kasus. Dataset waktu, iradiansi matahari, dan suhu lingkungan diperoleh dari Photovoltaic Geographical Information System di wilayah Yogyakarta, Indonesia pada tanggal 1 Januari 2007 [14].

Model terdistribusi berbasis IEC 61499 menyimulasikan model jaringan listrik arus searah skala mikro (Gambar 1). Model ini terdiri dari panel surya, baterai, beban listrik, dan kontroler [11]. Sistem baterai yang digunakan sejumlah tiga baterai.

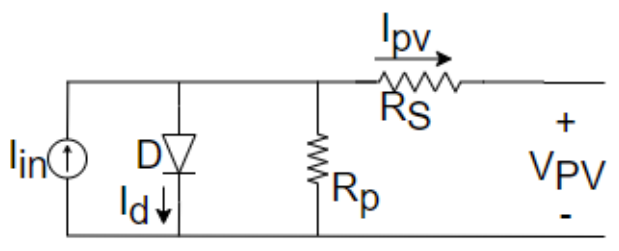

Gambar 2. Model panel surya [15]

Rangkaian listrik model panel surya digambarkan sesuai Gambar 2. Panel surya dimodelkan menggunakan Persamaan 1, 2, dan 3 [15]. Pada Persamaan 1, arus $I_{p v}$ merupakan selisih dari arus yang dihasilkan sel surya $\left(I_{\text {in }}\right)$ dengan arus yang mengalir di dioda $\mathrm{D}$ dan arus yang mengalir di resistor $R_{p}$. Arus di dioda D dipengaruhi oleh arus saturasi dioda $\left(I_{o}\right)$, tegangan yang dihasilkan panel surya $\left(V_{p v}\right)$, hambatan seri sel surya $\left(R_{s}\right)$, dan faktor dioda ideal $(a)$. Konstanta qadalah muatan elektron $\left(1,60217646 \times 10^{-19} \mathrm{C}\right)$. Nilai $N_{s}$ adalah banyak sel surya yang tersusun secara seri. Nilai $k$ adalah konstanta Boltzmann $\left(1,380653 \times 10^{23} \mathrm{~J} / K\right)$. Nilai $T$ adalah temperatur lingkungan aktual dalam satuan Kelvin. Nilai $N_{p}$ adalah banyak sel surya yang tersusun secara paralel. Nilai $\Delta T$ merupakan selisih temperatur lingkungan aktual dengan temperatur lingkungan saat kondisi STC $\left(T_{n}\right)$. Nilai $G$ dan $G_{n}$ secara berturut-turut adalah iradiansi matahari aktual dan iradiansi matahari saat kondisi STC. Kondisi STC adalah kondisi standar pengujian panel surya yakni ketika temperatur lingkungan bernilai 298.15 K dan iradiansi matahari bernilai $1000 \mathrm{~W} / \mathrm{m}^{2}$ [16].

$$
\begin{gathered}
I_{p v}=I_{\text {in }}-I_{o}\left\{\exp \left[\frac{\left.q\left(V_{p v}\right)+R_{s} I_{p v}\right)}{N_{s} k T a}\right]-1\right\} \\
-\frac{\left(V_{p v}+R_{s} I_{p v}\right)}{R_{p}} \\
I_{\text {in }}=\left[\frac{\left(R_{P}+R_{s}\right)}{R_{p}} I_{s c, n}+K_{I} \Delta T\right] \frac{G}{G_{n}} \\
I_{o}=\frac{\left(I_{s c, n}+K_{I} \Delta T\right)}{\exp \left[\frac{q\left(V_{o c, n}+K_{V} \Delta T\right)}{N_{s} k T a}\right]-1}
\end{gathered}
$$

Nilai $a, R_{s}$, dan $R_{p}$ dikalkulasi berdasarkan parameter yang tertulis di Tabel 3. Hasil kalkuasi parameter tersebut adalah $a=1,3, R_{s}=0,021 \Omega$, dan $R_{p}=415,405 \Omega$ [15]. 
Tabel 3. Karakteristik modul panel surya Kyocera KC200GT [17]

\begin{tabular}{clcc}
\hline No. & \multicolumn{1}{c}{ Parameter } & Simbol & Nilai \\
\hline 1 & Tegangan nominal saat sirkuit terbuka & $V_{o c, n}$ & $32,9 \mathrm{~V}$ \\
\hline 2 & Arus nominal saat sirkuit hubung pendek & $I_{s c, n}$ & $8,21 \mathrm{~A}$ \\
\hline 3 & Tegangan saat MPP & $V_{m p}$ & $26,3 \mathrm{~V}$ \\
\hline 4 & Arus saat MPP & $I_{m p}$ & $7,61 \mathrm{~A}$ \\
\hline 5 & Koefisien temperatur saat sirkuit terbuka & $K_{V}$ & $-0,1230$ \\
& & & $\mathrm{~V} / \mathrm{K}$ \\
\hline 6 & Koefisien temperatur saat sirkuit hubung pendek & $K_{I}$ & 0,0032 \\
& & & $\mathrm{~A} / \mathrm{K}$ \\
\hline 7 & Daya maksimum ekspermtental & $P_{\max }$ & 200,143 \\
\hline
\end{tabular}

Persamaan 4 dan 5 merupakan model baterai [18]. Nilai $R_{S}$ dan $V_{o c}$ secara berturut-turut adalah resistansi internal baterai dan tegangan baterai. Nilai $E_{o}, K, Q, \mathrm{~A}$, dan $B$ secara berturut-turut adalah nilai tegangan saat rangkaian terbuka, polarisasi tegangan (V), kapasitas baterai (Ah), konstanta tegangan eksponensial (V/Ah), dan konstanta kapasitas eksponensial (Ah). Pada penelitian ini, baterai yang digunakan adalah baterai NiMH 1,2 V berkapasitas 6,5 Ah dengan parameter seperti tertera pada Tabel 4.

Persamaan 6 merupakan persamaan State of Charge (SoC). SoC menunjukkan kapasitas baterai yang tersedia. Persamaan 7 merupakan persamaan untuk menghitung daya yang perlu disuplai oleh baterai $\left(P_{b a t, r e q}\right)$. Nilai $P_{\text {bat,req }}$ adalah selisih dari daya yang diminta oleh beban $\left(P_{\text {load }}\right)$ dan daya yang disuplai panel surya $\left(P_{p v}\right)$. Persamaan 8 merupakan persamaan untuk menghitung pengisian atau pengurasan daya $\left(I_{b a t}\right)$. Nilai $I_{b a t}$ pada kondisi awal dikalkulasikan menurut Persamaan 9.

$$
\begin{gathered}
V_{o c}=E_{o}-K \frac{Q}{Q-\int I_{b a t} d t} \int I_{b a t} d t \\
+A \exp \left(-B \int I_{b a t} d t\right) \\
V_{b a t}=V_{o c}-I_{b a t} R_{S} \\
S o C=S o C_{\text {init }}\left(1-\frac{\int I_{b a t} d t}{Q}\right) \\
P_{b a t, r e q}=P_{\text {load }}-P_{p v} \\
I_{\text {bat }}=\frac{P_{b a t}}{V_{b a t}} \\
I_{b a t}=\left(1-\frac{S o C_{\text {init }}}{100}\right) Q
\end{gathered}
$$

Tabel 4. Spesifikasi baterai [18]

\begin{tabular}{cc}
\hline Parameter & Nilai \\
\hline$E_{o}(V)$ & 1,2 \\
\hline$R_{S}(\Omega)$ & 0,02 \\
\hline$K(\mathrm{~V} / \mathrm{Ah})$ & 0,0014 \\
\hline $\mathrm{A}(\mathrm{V})$ & 0,111 \\
\hline $\mathrm{B}(\mathrm{Ah})$ & 2,3077 \\
\hline
\end{tabular}

Model PV dan baterai divalidasi dengan mengomparasikan data dari dokumen teknis dengan data hasil simulasi. Komparasi tersebut dilakukan menggunakan persamaan Root Mean Square Error (RMSE) sesuai Persamaan 10 [19]. Nilai $y_{i}$ adalah data dari dokumen teknis dan nilai $x_{i}$ adalah data hasil simulasi.

$$
R M S E=\sqrt{\frac{\sum_{i=1}^{n}\left(y_{i}-x_{i}\right)^{2}}{n}}
$$

Tiga konverter DC/DC digunakan dalam penelitian ini (Gambar 3). Tegangan bus $\left(V_{d c}\right)$ dimodelkan sesuai Persamaan 11. $P_{d c 1}, P_{d c 2}$, dan $P_{d c 3}$ merupakan daya dari konverter DC/DC 1, DC/DC 2, dan DC/DC 3. Nilai $C$ adalah nilai kapasitansi kapasitor dalam satuan Farad. Nilai $V_{\text {ref }}$ adalah tegangan bus maksimal. Persamaan 12 menjelaskan bahwa daya keluaran $P_{\text {out }}$ sebanding dengan edisiensi konversi daya $\eta$ dengan daya masukan $P_{\text {in }}$ [20].

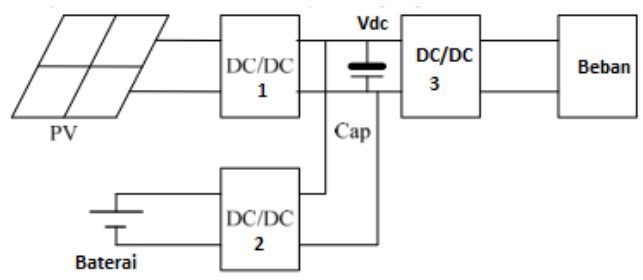

Gambar 3. Konfigurasi jaringan listrik tipe DC skala mikro [11]

$$
\begin{gathered}
V_{d c}=V_{r e f}+\int \frac{\left(P_{d c 1}+P_{d c 2}-P_{d c 3}\right)}{V_{d c}} d t \\
P_{\text {out }}=\eta P_{\text {in }}
\end{gathered}
$$

Beban listrik dimodelkan sesuai Persamaan 13 [21]. Nilai $P_{\text {load }}, V_{\text {load }}, I_{\text {load }}$, dan $R$ secara berturut-turut adalah daya beban, tegangan beban, arus beban, dan resistansi. Hubungan antara $V_{\text {load }}$ dan $I_{\text {load }}$ dijelaskan oleh Persamaan 14.

$$
\begin{gathered}
P_{\text {load }}=\frac{V^{2} \text { load }}{R} \\
I_{\text {load }}=\frac{P_{\text {load }}}{V_{\text {load }}}
\end{gathered}
$$

Penelitian ini menganalisis empat algoritma yakni algoritma berbasis satu nilai state of charge $(\mathrm{SoC})$, algoritma berbasis dua nilai $S o C$, algoritma tanpa berbasis 
nilai $S o C$, dan algoritma proteksi. Algoritma berbasis satu nilai $S o C$, algoritma berbasis dua nilai $S o C$, dan algoritma tanpa berbasis nilai $S o C$ merupakan algoritma untuk memilih baterai yang akan diisi atau dikuras. Algoritma proteksi berfungsi untuk memutuskan apakah baterai yang terpilih tersebut layak diisi atau dikuras berdasarkan kondisi SoC dan besar arus pengisian atau arus pengurasan. Hal tersebut berfungsi untuk mencegah pengurasan atau pengisian daya berlebihan yang dapat merusak baterai. Algoritma proteksi diimplementasikan di algoritma berbasis satu nilai $S o C$, algoritma berbasis dua nilai $S o C$, dan algoritma tanpa berbasis nilai $S o C$.

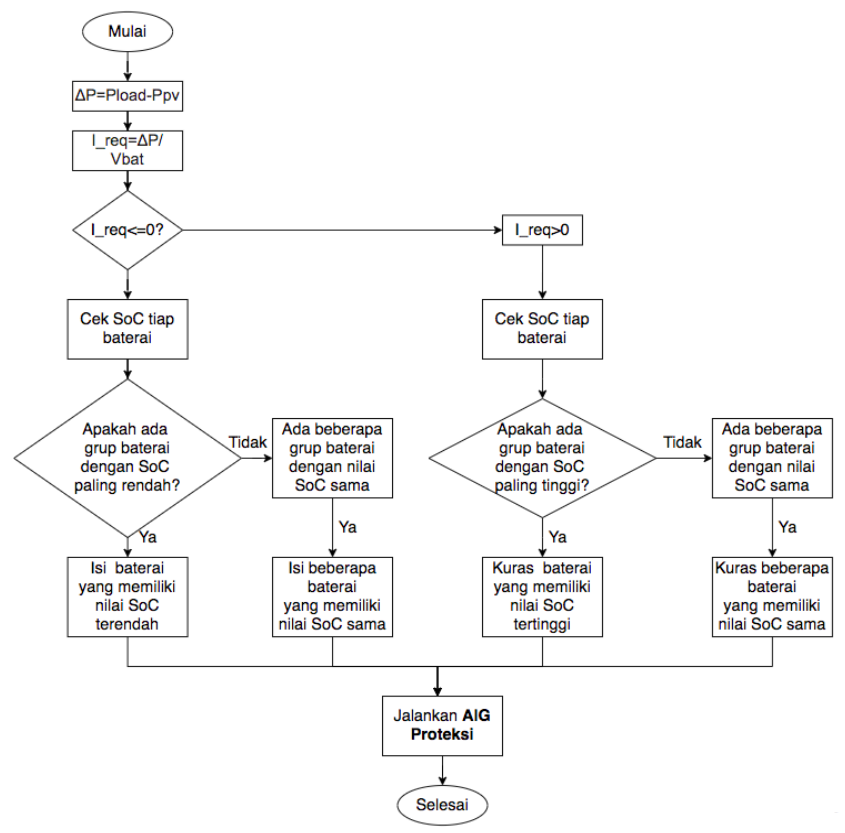

Gambar 4. Algoritma berbasis 1 nilai $S o C$

Gambar 4 menjelaskan diagram alir dari algoritma berbasis 1 nilai $S o C$. Pada mode pengurasan daya baterai, algoritma berbasis 1 nilai $S o C$ memilih satu baterai dengan kondisi $S o C$ terendah. Algoritma berbasis 1 nilai SoC memilih satu baterai dengan kondisi $S o C$ tertinggi pada mode pengisian daya baterai.

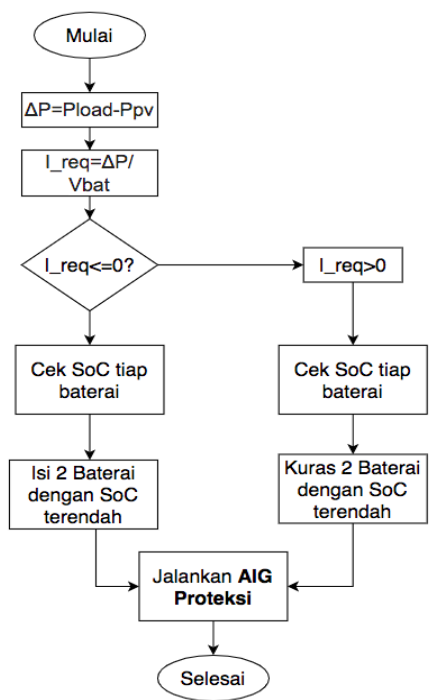

Gambar 5. Algoritma berbasis 2 nilai $S o C$
Gambar 5 adalah diagram alir dari algoritma berbasis 2 nilai SoC. Pada mode pengurasan daya baterai, algoritma berbasis 2 nilai $S o C$ memilih dua baterai dengan kondisi $S o C$ terendah. Algoritma berbasis 2 nilai $S o C$ memilih dua baterai dengan kondisi $S o C$ tertinggi pada mode pengisian daya baterai.

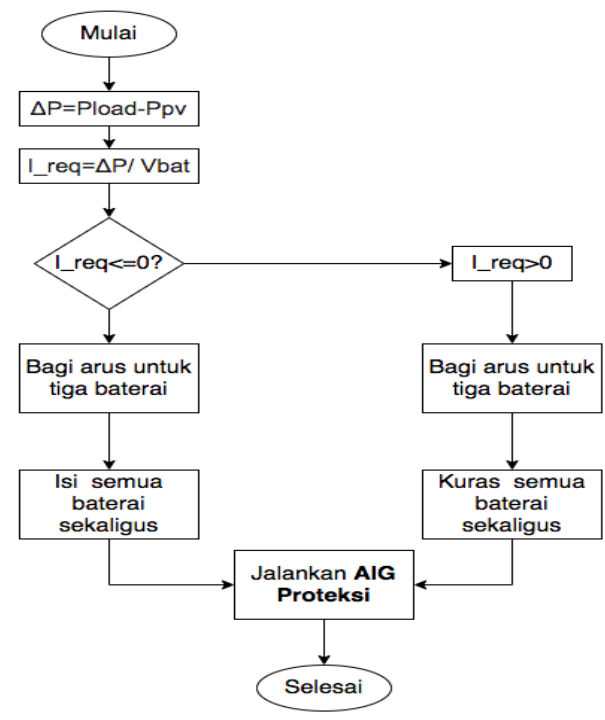

Gambar 6. Algoritma tanpa berbasis nilai $\mathrm{SoC}$

Gambar 6 adalah diagram alir dari algoritma tanpa berbasis nilai $S o C$. Pada mode pengurasan daya baterai, algoritma tanpa berbasis nilai $\mathrm{SoC}$ memilih tiga baterai dengan untuk dikuras sekaligus. Algoritma tanpa berbasis nilai $S o C$ memilih tiga baterai dengan untuk diisi sekaligus pada mode pengisian daya baterai.

Gambar 7 adalah diagram alir dari algoritma proteksi. Algoritma ini mengatur agar baterai memiliki nilai $S o C$ berada di rentang $\mathrm{SoC}$ minimum dan $\mathrm{SoC}$ maksimum. Selain itu, algoritma ini juga mengatur agar arus yang menguras atau mengisi baterai tidak berlebihan.

Validasi model panel surya dilakukan dengan cara mengomparasikan hasil pengujian model PV dengan data dari dokumen teknis modul PV tersebut. Data yang diambil dari pengujian ini adalah data tegangan PV, arus PV, dan daya yang dihasilkan PV.

Model baterai yang dibuat adalah baterai Pansonic HHR 650D [22]. Validasi model baterai ini dilakukan dengan cara mengomparasikan hasil pengujian model baterai dengan data dari dokumen teknis model baterai tersebut. Data yang diambil dari pengujian ini adalah data tegangan baterai, arus baterai, daya baterai, dan $S o C$.

Model tegangan bus akan divalidasi dengan cara memberi sinyal uji berupa daya panel surya, daya baterai, dan daya beban. Skenario pengujian pertama adalah ketika jumlah daya panel surya dan daya baterai lebih besar daripada daya beban. Skenario pengujian kedua adalah ketika jumlah daya panel surya dan daya baterai lebih kecil daripada daya beban. Data yang diambil adalah data tegangan bus. 


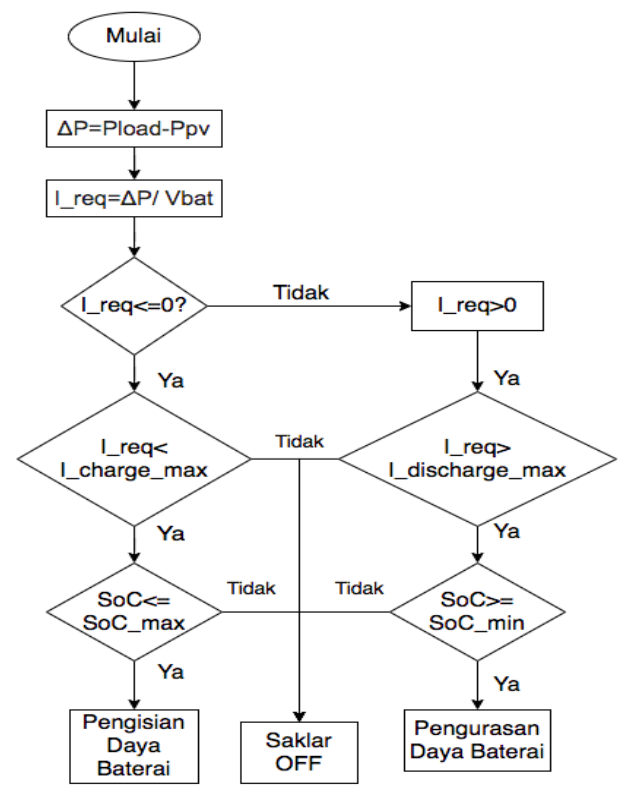

Gambar 7. Algoritma proteksi baterai

Model beban listrik akan divalidasi dengan memberi masukan sinyal lereng variabel resistansi. Data yang diambil adalah data resistansi, tegangan beban, arus beban, dan daya beban.

Studi kasus disimulasikan untuk menguji performa algoritma manajemen baterai yang telah dikembangkan. Jaringan listrik tersebut dirancang agar memenuhi kebutuhan beban listrik yang menyala bersamaan selama 7 jam. Jaringan tersebut harus memiliki tegangan bus yang stabil pada nilai $24 \mathrm{~V}$. Daftar kebutuhan beban listrik terdapat pada Tabel 5. Kebutuhan total menurut tabel tersebut adalah $350 \mathrm{~W}$. Berdasarkan pertimbangan efisiensi konverter DC/DC sebesar $90 \%$ dan nilai rugirugi daya yang dikonsumsi kabel sepanjang 20 meter, kebutuhan beban dialokasikan sebanyak $400 \mathrm{~W}$.

Tabel 5. Daftar kebutuhan beban listrik

\begin{tabular}{cccccc}
\hline No. & $\begin{array}{c}\text { Perangkat } \\
\text { Elektronik }\end{array}$ & Banyak & Satuan & $\begin{array}{c}\text { Daya } \\
(\mathbf{W})\end{array}$ & $\begin{array}{c}\text { Daya Total } \\
(\mathbf{W})\end{array}$ \\
\hline 1 & Laptop & 5 & buah & 40 & 200 \\
\hline 2 & HP & 4 & buah & 5 & 20 \\
\hline 3 & Lampu & 10 & buah & 10 & 100 \\
\hline
\end{tabular}

Sebuah baterai lithium-ion US26659 memiliki kapasitas maksimum sebesar 2,9 Ah dan tegangan nominal sebesar 3,2 V [23]. Sebuah grup baterai yang tersusun dari sejumlah baterai perlu dipertimbangkan terkait susunan seri $\left(N_{s}\right)$ dan paralel $\left(N_{p}\right)$. Nilai susunan seri $\left(N_{S}\right)$ dan paralel $\left(N_{p}\right)$ secara berturut-turut ditetapkan bernilai 8 dan 47. Pada penelitian ini, baterai akan dikonfigurasikan menjadi dua grup dan tiga grup. Masing-masing konfigurasi tersebut memiliki susunan seri dan paralel yang berbeda berdasarkan perhitungan yang sama. Tabel 6 menunjukkan konfigurasi baterai beserta nilai susunan seri dan paralelnya.
Tabel 6. Daftar Konfigurasi Baterai

\begin{tabular}{llll}
\hline Jumlah Grup & Grup ke-1 & Grup ke-2 & Grup ke-3 \\
\hline 1 & $\mathrm{Ns}=8$ & - & - \\
& $\mathrm{Np}=47$ & & - \\
\hline 2 & $\mathrm{Ns}=8$ & $\mathrm{Ns}=8$ & \\
\hline \multirow{2}{*}{3} & $\mathrm{~Np}=24$ & $\mathrm{~Np}=23$ & $\mathrm{Ns}=8$ \\
& $\mathrm{Ns}=8$ & $\mathrm{Ns}=8$ & $\mathrm{~Np}=15$ \\
\hline
\end{tabular}

Tabel 7. Daftar konstanta pada masing-masing konfigurasi baterai [11]

\begin{tabular}{|c|c|c|c|c|c|c|}
\hline $\begin{array}{c}\text { Konfigurasi } \\
\text { Baterai }\end{array}$ & $\begin{array}{l}V_{\text {full }} \\
Q_{\text {full }}\end{array}$ & $\begin{array}{l}V_{\text {exp }} \\
Q_{\text {exp }}\end{array}$ & $\begin{array}{l}V_{\text {nom }} \\
Q_{\text {nom }}\end{array}$ & $\begin{array}{c}\mathbf{A} \\
(\mathbf{V} / \mathbf{A h}) \\
\end{array}$ & $\begin{array}{c}\text { B } \\
\text { (Ah) }\end{array}$ & $\begin{array}{c}\mathbf{K} \\
(\mathbf{A h}) \\
\end{array}$ \\
\hline $\begin{array}{c}\mathrm{Ns}=8 \\
\mathrm{~Np}=47\end{array}$ & $\begin{array}{c}27,2 \\
141 \\
\end{array}$ & $\begin{array}{c}26,4 \\
9,4 \\
\end{array}$ & $\begin{array}{c}25,6 \\
133,9\end{array}$ & 0,8 & 0,32 & 0,4 \\
\hline $\begin{array}{c}\mathrm{Ns}=8 \\
\mathrm{~Np}=24\end{array}$ & $\begin{array}{c}27,2 \\
72 \\
\end{array}$ & $\begin{array}{c}26,4 \\
4,8 \\
\end{array}$ & $\begin{array}{l}25,6 \\
68,4 \\
\end{array}$ & 0,8 & 0,62 & 0,4 \\
\hline $\begin{array}{c}\mathrm{Ns}=8 \\
\mathrm{~Np}=23\end{array}$ & $\begin{array}{c}27,2 \\
69 \\
\end{array}$ & $\begin{array}{c}26,4 \\
4,6 \\
\end{array}$ & $\begin{array}{c}25,6 \\
65,55 \\
\end{array}$ & 0,8 & 0,65 & 0,4 \\
\hline $\begin{array}{c}\mathrm{Ns}=8 \\
\mathrm{~Np}=16\end{array}$ & $\begin{array}{c}27,2 \\
48 \\
\end{array}$ & $\begin{array}{c}26,4 \\
3,2 \\
\end{array}$ & $\begin{array}{l}25,6 \\
45,6 \\
\end{array}$ & 0,8 & 0,93 & 0,4 \\
\hline $\begin{array}{c}\mathrm{Ns}=8 \\
\mathrm{~Np}=15\end{array}$ & $\begin{array}{c}27,2 \\
45\end{array}$ & $\begin{array}{c}26,4 \\
3,0\end{array}$ & $\begin{array}{c}25,6 \\
42,75\end{array}$ & 0,8 & 1 & 0,4 \\
\hline
\end{tabular}

Tabel 7 menunjukkan nilai tegangan dan kapasitas pada masing-masing konfigurasi baterai. Nilai arus pengurasan maksimum merupakan perkalian $Q_{\text {full }}$ sebuah baterai dikalikan jumlah rangkaian paralel $N_{p}$.

Tahap awal yang dilakukan pada penelitian ini adalah melakukan variasi konfigurasi baterai. Baterai dikonfigurasikan menjadi satu, dua, dan tiga grup. Tahap awal ini berkaitan dengan tujuan penelitian yaitu mendapatkan perbandingan kuantitatif nilai neraca daya, nilai tegangan bus, dan konsumsi baterai pada masingmasing konfigurasi baterai. Tahap terakhir yang dilakukan adalah melakukan implementasi algoritma manajemen baterai yang telah dikembangkan pada sistem penyimpan energi yang dikonfigurasikan menjadi tiga grup baterai. Tahap ini berkaitan dengan tujuan penelitian yaitu mendapatkan perbandingan kuantitatif nilai neraca daya, tegangan bus, dan konsumsi baterai pada masingmasing algoritma.

\section{HASIL DAN PEMBAHASAN}

Hasil penelitian dijelaskan dalam dua bagian. Bagian pertama menjelaskan tentang hasil validasi model. Bagian kedua menjelaskan tentang hasil simulasi studi kasus.

\section{A. Hasil Validasi Model}

Validasi lima model yang telah dibuat pada penelitian ini akan dijelaskan pada bagian ini. Lima model tersebut adalah model panel surya, baterai, beban listrik, konverter DC/DC, dan tegangan bus. 


\section{1) Hasil Validasi Model Panel Surya}

Gambar 8 menunjukkan komparasi data arus panel surya hasil simulasi dengan data dari dokumen teknis. Nilai RMSE yang didapatkan dari komparasi ini adalah 0,15 . Model panel surya sudah cukup mendekati panel surya sebenarnya karena nilai RMSE mendekati 0 .

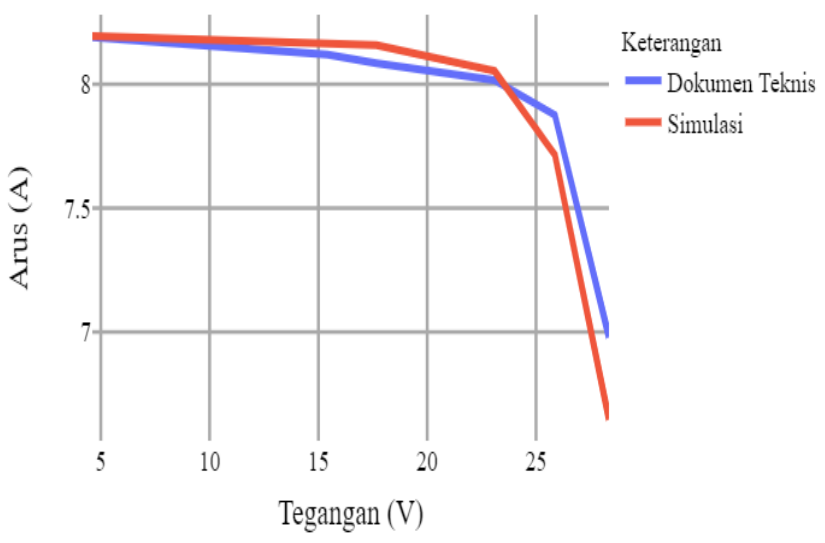

Gambar 8. Arus dan tegangan panel surya

\section{2) Hasil Validasi Model Baterai}

Gambar 9 adalah nilai tegangan baterai dari sebuah baterai yang dikuras dayanya selama 3.572 detik. Hasil simulasi menunjukkan bahwa tegangan turun drastis setelah 3200 detik. Hal terjadi ini ketika kapasitas baterai berada pada nilai $10 \%$ dari kapasitas mula-mula. Model ini memiliki nilai RMSE 0,06. Model ini sudah cukup sesuai dengan baterai yang sebenarnya karena nilai RMSE mendekati 0.

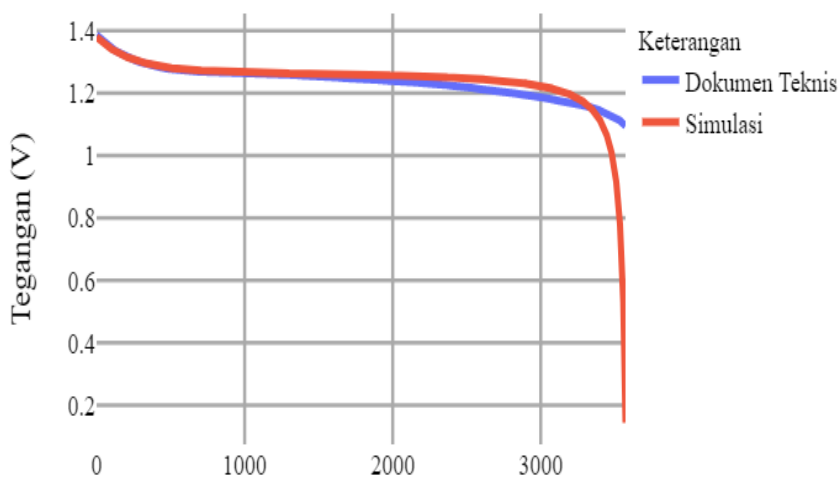

Waktu (s)

Gambar 9. Hasil validasi model baterai

\section{3) Hasil Validasi Model Beban Listrik}

Gambar 10 menunjukkan sinyal lereng bergerak dari $0 \Omega$ hingga $10 \Omega$ selama satu detik. Nilai daya listrik beban tersebut semakin menurun sepanjang waktu. Hal ini menunjukkan bahwa daya listrik beban berbanding terbalik terhadap nilai resistansi.

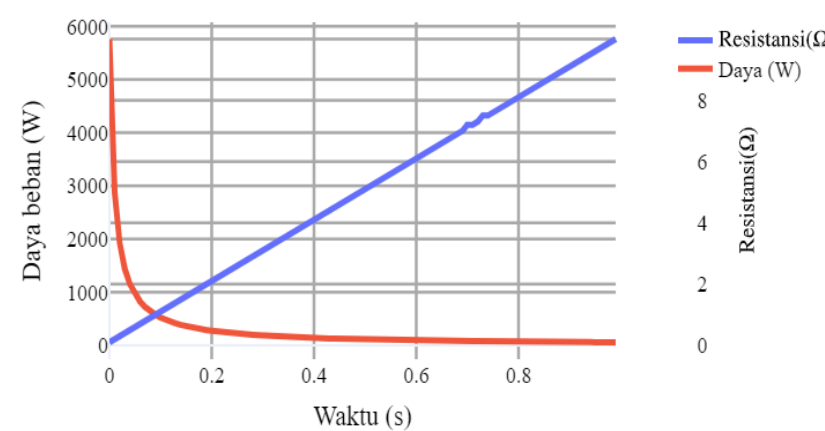

Gambar 10. Variasi resistansi beban dan daya beban

Pada Gambar 11, kurva arus listrik beban memiliki bentuk yang serupa dengan kurva daya listrik beban. Hal ini disebabkan tegangan beban bernilai ajeg yakni $24 \mathrm{~V}$. Bentuk kurva ini sesuai dengan Persamaan 14 yang menunjukkan bahwa arus listrik beban berbanding lurus dengan daya listrik beban.

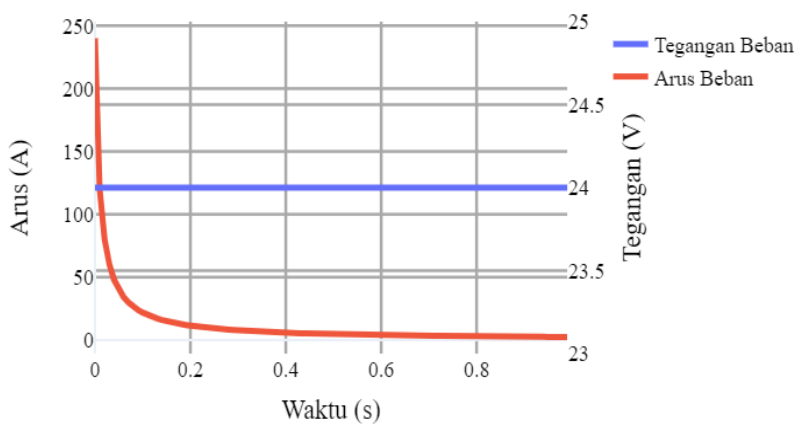

Gambar 11. Tegangan dan arus beban

\section{4) Hasil Validasi Model Tegangan Bus}

Gambar 12 adalah hasil uji skenario kedua. Nilai tegangan $V_{\text {ref }}$ ditetapkan bernilai $24 \mathrm{~V}$. Hasil penggambaran menunjukkan bahwa tegangan kapasitor terus menurun sepanjang waktu dari $24 \mathrm{~V}$ hingga mencapai $0 \mathrm{~V}$ ketika mencapai detik ke-29.

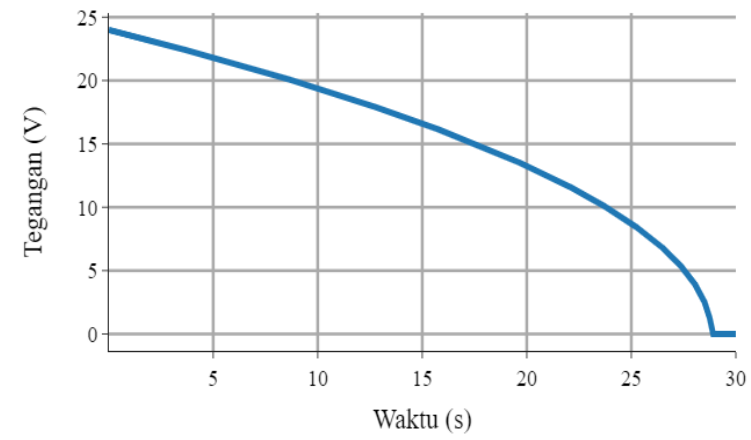

Gambar 12. Tegangan bus pada kondisi daya suplai lebih kecil dari permintaan daya

Gambar 13 adalah hasil uji skenario pertama. Nilai tegangan $V_{\text {ref }}$ ditetapkan bernilai $12 \mathrm{~V}$. Hasil pengambaran menunjukkan bahwa tegangan kapasitor terus meningkat sepanjang waktu dari $12 \mathrm{~V}$ hingga mencapai $24 \mathrm{~V}$ ketika mencapai detik ke-21,6. 


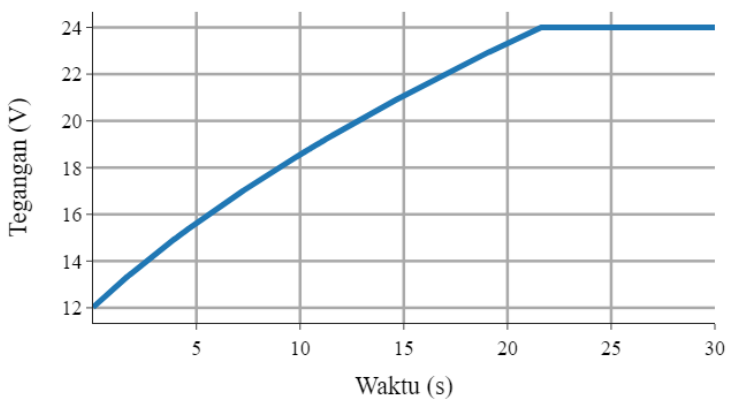

Gambar 13. Tegangan bus pada kondisi daya suplai lebih besar dari permintaan daya

Kedua bentuk kurva ini menunjukkan bahwa tegangan bus berbanding lurus dengan akumulasi arus yang mengisi atau menguras kapasitor. Apabila suplai daya lebih rendah dibanding permintaan daya, maka nilai suku ke-2 pada Persamaan 11 bernilai negatif. Hal ini menyebabkan tegangan bus menurun. Apabila suplai daya melebihi permintaan daya, maka nilai suku ke-2 pada Persamaan 11 bernilai positif. Hal ini menyebabkan tegangan bus meningkat.

\section{5) Hasil Validasi Konverter DC/DC}

Gambar 14 adalah hasil penggambaran daya keluaran dan daya masukan terhadap waktu. Nilai daya masukan $P_{1}, P_{2}$, dan $P_{3}$ secara beturut-turut adalah $90 \mathrm{~W}, 50 \mathrm{~W}$, dan $20 \mathrm{~W}$. Nilai daya keluaran $P_{\text {lout }}, P_{2 \text { out }}$, dan $P_{3 \text { out }}$ secara beturut-turut adalah $85 \mathrm{~W}, 46.25 \mathrm{~W}$, dan $18 \mathrm{~W}$. Nilai $P_{1}$ turun $5 \%, P_{2}$ turun $7.5 \%$, dan $P_{3}$ turun $10 \%$. Hasil ini sesuai dengan Persamaan 12.

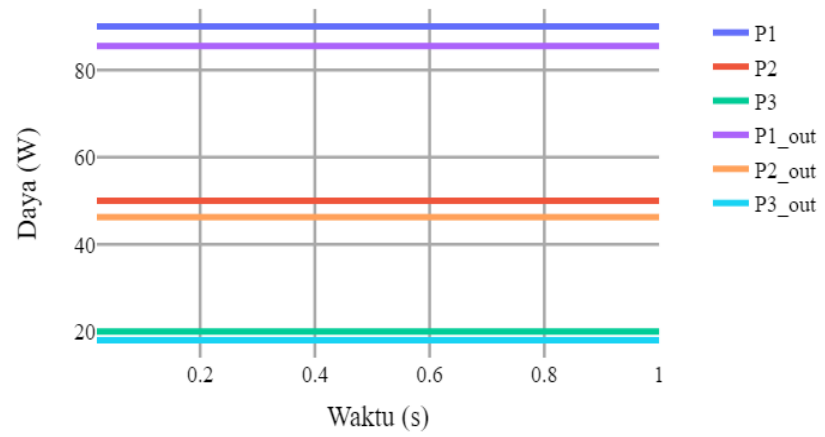

Gambar 14. Hasil uji model konverter arus searah/DC

\section{B. Hasil Simulasi Studi Kasus}

Gambar 15 merupakan data iradiansi matahari yang digunakan dalam simulasi pada tanggal 1 Januari 2007. Data beban listrik dibuat berdasarkan perhitungan studi kasus. Gambar 16 merupakan beban listrik yang disimulasikan.

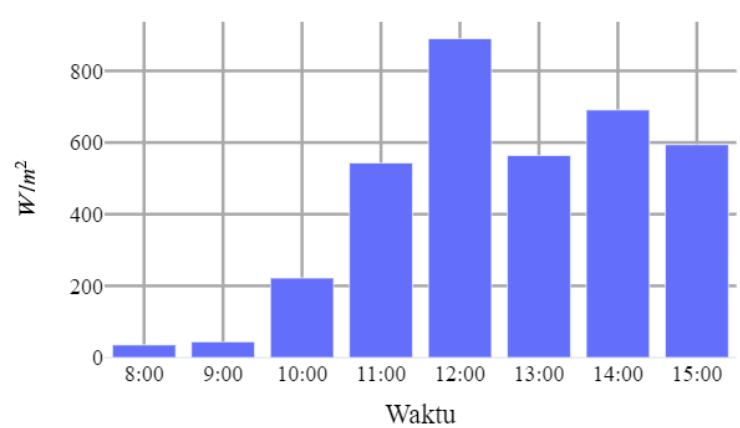

Gambar 15. Profil iradiansi matahari

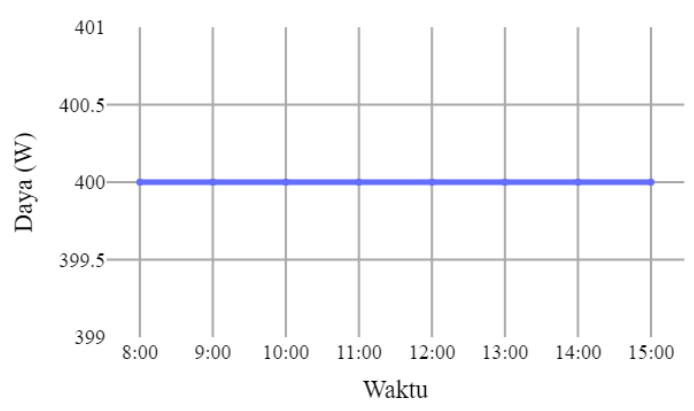

Gambar 16. Profil beban listrik

1) Komparasi Hasil Simulasi dengan Variasi Konfigurasi Baterai

Komparasi hasil simulasi dengan variasi konfigurasi baterai ditunjukkan oleh Gambar 17, 18, 19, dan 20. Analisis ini dilakukan untuk mengetahui pengaruh konfigurasi baterai terhadap keseimbangan neraca daya, nilai tegangan bus, dan tingkat konsumsi baterai.

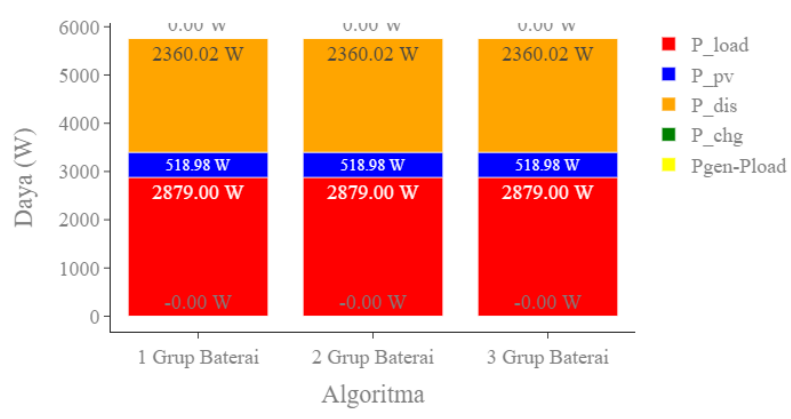

Gambar 17. Komparasi neraca daya

Tiga variasi konfigurasi grup baterai disimulasikan pada penelitian ini. Variasi tersebut meliputi konfigurasi 1 grup baterai, 2 grup baterai, dan 3 grup baterai. Semua konfigurasi tersebut mampu menjamin suplai beban listrik. Gambar 17 menunjukkan bahwa baterai dan panel surya mampu memenuhi permintaan listrik dari beban listrik. 


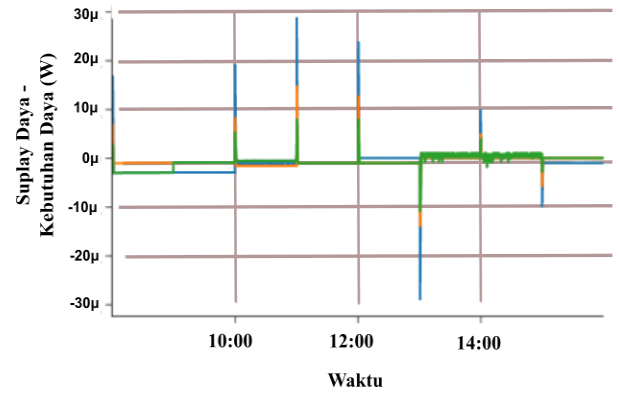

- 1 Grup Baterai

- 2 Grup Baterai

- 3 Grup Baterai

Gambar 18. Komparasi nilai selisih suplai daya dengan konsumsi daya

Gambar 18 menunjukkan bahwa lonjakan selisih suplai daya listrik dengan konsumsi daya listrik terjadi di semua konfigurasi baterai. Meskipun demikian, lonjakan selisih daya tersebut masih mampu menjaga kestabilan tegangan bus di sekitar nilai $24 \mathrm{~V}$. Hal ini ditunjukkan oleh Gambar 20.

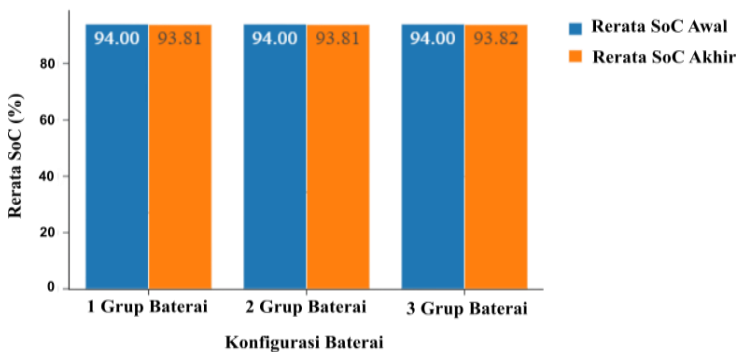

Gambar 19. Komparasi nilai SoC baterai

Penurunan nilai SoC terjadi di semua konfigurasi baterai seperti yang ditunjukkan oleh Gambar 19. Gambar ini menjelaskan rerata $S o C$ di awal dan di akhir simulasi. Nilai $S o C$ pada konfigurasi 1 dan 2 grup baterai menurun sebesar $0,19 \%$. Nilai $S o C$ pada konfigurasi 3 grup baterai menurun sebesar $0,18 \%$. Meskipun hasil penurunan nilai SoC pada konfigurasi 3 grup lebih rendah, nilainya tidak berbeda jauh dibandingkan pada konfigurasi 1 dan 2 grup baterai.

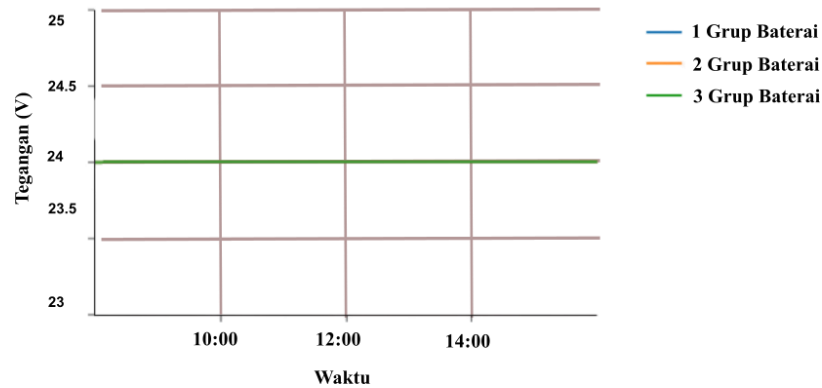

Gambar 20. Komparasi nilai tegangan bus

Hasil komparasi hasil simulasi dengan variasi konfigurasi grup baterai terangkum pada Tabel 8. Semua konfigurasi grup baterai mampu menjamin keseimbangan neraca daya. Nilai tegangan bus stabil di nilai $24 \mathrm{~V}$ di semua konfigurasi grup baterai. Penggunaan konfigurasi grup baterai yang berbeda menyebabkan konsumsi baterai yang berbeda meskipun tidak signifikan. Konfigurasi 3 grup baterai memiliki tingkat konsumsi listrik lebih hemat $0,1 \%$ dibandingkan dua konfigurasi grup baterai yang lainnya.
Tabel 8. Rangkuman Komparasi Hasil Simulasi dengan Variasi Konfigurasi Baterai

\begin{tabular}{lllll}
\hline $\begin{array}{l}\text { Konfigurasi } \\
\text { Baterai }\end{array}$ & Algoritma & $\begin{array}{l}\text { Defisit } \\
\text { Neraca } \\
\text { Daya } \\
\text { (W) }\end{array}$ & $\begin{array}{l}\text { Rerata } \\
\text { Penurunan } \\
\text { Tegangan } \\
\text { Bus } \\
(\mathbf{V})\end{array}$ & $\begin{array}{l}\text { Rerata } \\
\text { Penurunan } \\
\text { Nilai } \\
\text { SoC } \\
(\boldsymbol{\%})\end{array}$ \\
\hline 1 grup & $\begin{array}{l}\text { Tanpa } \\
\text { berbasis } \\
\text { nilai SoC }\end{array}$ & 0 & 0 & 0,19 \\
\hline 2 grup & $\begin{array}{l}\text { Tanpa } \\
\text { berbasis } \\
\text { nilai SoC }\end{array}$ & 0 & 0 & 0,19 \\
\hline 3 grup & $\begin{array}{l}\text { Tanpa } \\
\text { berbasis } \\
\text { nilai SoC }\end{array}$ & 0 & 0 & 0,18 \\
\hline
\end{tabular}

2) Komparasi Hasil Simulasi dengan Variasi Algoritma Manajemen Baterai

Komparasi hasil simulasi dengan variasi algoritma manajemen baterai ditunjukkan oleh Gambar 21, 22, 23, dan 24. Analisis ini dilakukan untuk mengetahui pengaruh konfigurasi baterai terhadap keseimbangan neraca daya, nilai tegangan bus, dan tingkat konsumsi baterai. Ketiga algoritma tersebut diimplementasikan pada sistem penyimpan energi yang terdiri dari 3 grup baterai.

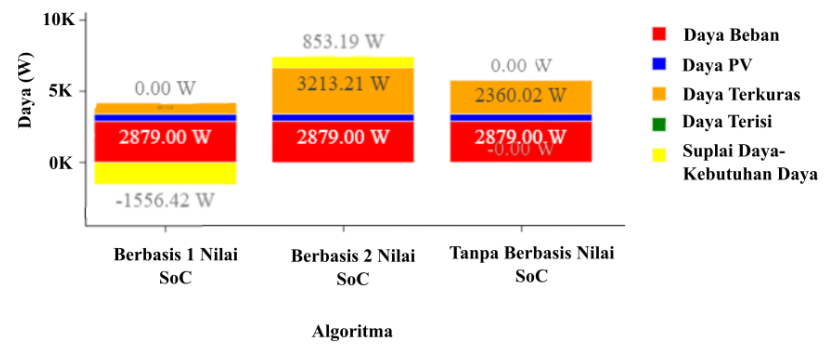

Gambar 21. Komparasi neraca daya

Tiga variasi algoritma manajemen baterai disimulasikan pada penelitian ini. Variasi tersebut meliputi algoritma berbasis 1 nilai $S o C, 2$ nilai $S o C$, dan tanpa berbasis nilai SoC. Gambar 18 menunjukkan bahwa algoritma berbasis 1 nilai $S o C$ tidak mampu memenuhi keseimbangan neraca daya. Penggunaan algoritma berbasis 1 nilai $S o C$ menyebabkan defisit sebesar 1.556,42 W. Penggunaan algoritma berbasis 2 nilai $S o C$ mampu memenuhi kebutuhan listrik meskipun ditemukan 853,19 W yang terbuang. Algoritma tanpa berbasis nilai $S o C$ mampu menjaga keseimbangan neraca.

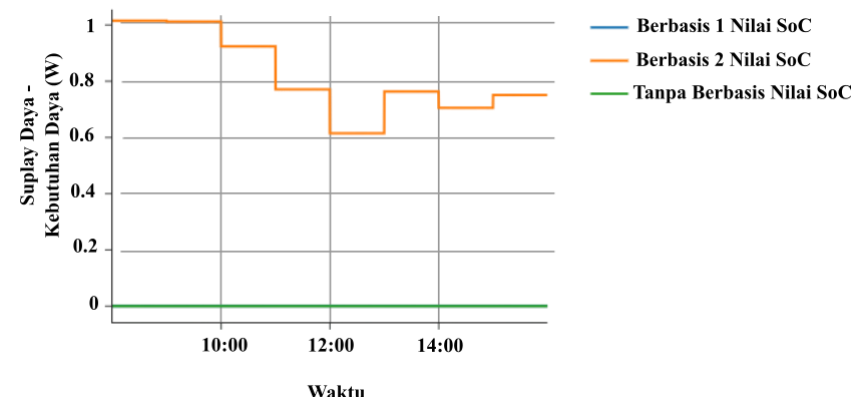

Gambar 22. Komparasi nilai selisih suplai daya dengan konsumsi daya 


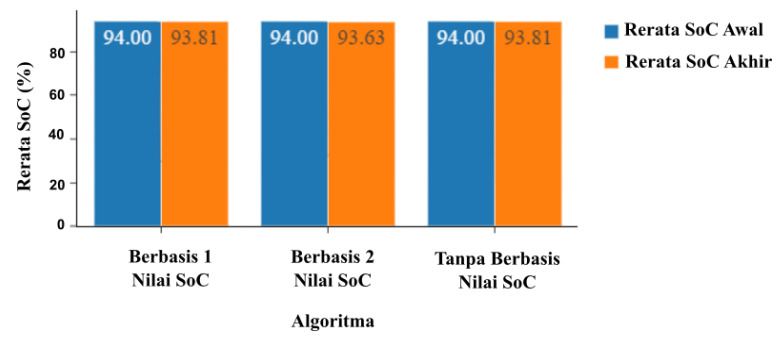

Gambar 23. Komparasi nilai SoC baterai

Gambar 22 menunjukkan bahwa penggunaan algoritma berbasis 2 nilai $S o C$ menyebabkan surplus daya sebesar 0,6 W hingga $1 \mathrm{~W}$. Surplus ini disebabkan oleh pengurasan baterai yang berlebih seperti yang ditunjukkan oleh Gambar 23. Penggunaan algoritma berbasis 1 nilai $S o C$ dan tanpa berbasis nilai $S o C$ tidak menyebabkan surplus maupun defisit neraca daya.

Penurunan nilai $S o C$ terjadi di semua konfigurasi baterai seperti yang ditunjukkan oleh Gambar 23. Gambar ini menjelaskan rerata $S o C$ di awal dan di akhir simulasi. Nilai $S o C$ pada algoritma berbasis 1 nilai $S o C$ menurun sebesar $0,19 \%$. Nilai SoC pada algoritma berbasis 2 nilai $\mathrm{SoC}$ menurun sebesar $0,37 \%$. Nilai $\mathrm{SoC}$ pada algoritma tanpa berbasis nilai $\mathrm{SoC}$ menurun sebesar $0,19 \%$. Penurunan terbesar terjadi di algoritma berbasis 2 nilai SoC karena ada pengurasan baterai yang berlebih seperti yang ditunjukkan oleh Gambar 21.

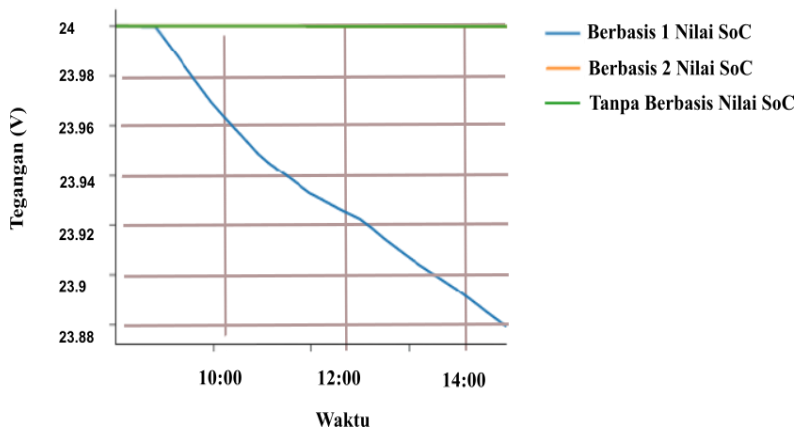

Gambar 24. Komparasi nilai tegangan bus

Gambar 24 menunjukkan bahwa penggunaan algoritma berbasis 1 nilai $\mathrm{SoC}$ menyebabkan tegangan bus menurun sebesar 0,18 V. Penggunaan algoritma tanpa berbasis nilai $\mathrm{SoC}$ dan algoritma berbasis 2 nilai $\mathrm{SoC}$ mampu menjaga kestabilan tegangan bus di angka $24 \mathrm{~V}$. Penurunan tegangan bus pada algoritma berbasis 1 nilai SoC terjadi akibat adanya defisit suplai daya.

Tabel 9. Rangkuman Komparasi Hasil Simulasi dengan Variasi Algoritma Manajemen Baterai

\begin{tabular}{llllc}
\hline $\begin{array}{l}\text { Konfigurasi } \\
\text { Baterai }\end{array}$ & Algoritma & $\begin{array}{l}\text { Defisit } \\
\text { Neraca Daya } \\
(\mathbf{W})\end{array}$ & $\begin{array}{l}\text { Rerata } \\
\text { Penurunan } \\
\text { Tegangan Bus } \\
(\mathbf{V})\end{array}$ & $\begin{array}{l}\text { Rerata } \\
\text { Penurunan } \\
\text { Nilai SoC } \\
(\%)\end{array}$ \\
\hline 1 grup & $\begin{array}{l}\text { Berbasis } 1 \\
\text { nilai SoC }\end{array}$ & $-1.556,42$ & 0,18 & 0,19 \\
\hline 2 grup & $\begin{array}{l}\text { Berbasis } 2 \\
\text { nilai SoC }\end{array}$ & 853,19 & 0 & 0,37 \\
\hline 3 grup & $\begin{array}{l}\text { Tanpa } \\
\text { berbasis } \\
\text { nilai SoC }\end{array}$ & 0 & 0 & 0,19 \\
\hline
\end{tabular}

Hasil komparasi hasil simulasi dengan variasi algoritma manajemen baterai terangkum pada Tabel 9 . Penerapan algoritma manajemen baterai yang berbeda menunjukkan hasil neraca daya yang berbeda. Algoritma tanpa berbasis nilai $\mathrm{SoC}$ menunjukkan performa paling baik karena mampu memenuhi kebutuhan listrik secara seimbang. Penerapan algoritma manajemen baterai yang berbeda menunjukkan kestabilan tegangan bus yang berbeda. Algoritma berbasis 2 nilai SoC dan algoritma tanpa berbasis nilai $S o C$ mampu menjaga kestabilan tegangan bus. Penerapan algoritma manajemen baterai yang berbeda menunjukkan tingkat konsumsi baterai yang berbeda. Algoritma berbasis 1 nilai $S o C$ dan algoritma tanpa berbasis nilai $S o C$ menunjukkan konsumsi baterai yang paling hemat dibanding algoritma berbasis 2 nilai SoC.

Rancangan studi kasus dengan kebutuhan listrik sebesar 3,2 kWh telah disimulasikan pada penelitian ini. Jaringan listrik skala mikro yang disimulasikan tersebut terdiri dari sebuah panel surya dengan kapasitas maksimum $200 \mathrm{~W}$ dan baterai berkapasitas $134 \mathrm{Ah}$. Beban disimulasikan menyala selama 7 jam secara bersamaan. Hasil simulasi menunjukkan bahwa jaringan listrik yang diuji tersebut dapat memenuhi kebutuhan beban listrik. Hasil simulasi dapat diimplementasikan dengan memperhatikan kondisi pengujian yang sama. Algoritma yang dapat diimplementasikan adalah algoritma tanpa berbasis $S o C$ karena mampu menjaga keseimbangan neraca daya lebih baik dibandingkan algoritma yang lain. Konfigurasi baterai yang dapat diimplementasikan adalah konfigurasi tiga grup baterai karena memiliki tingkat konsumsi listrik lebih hemat $0,1 \%$ dibanding konfigursi grup baterai yang lainnya.

\section{KESIMPULAN}

Pada penelitian ini, model jaringan listrik arus searah skala mikro yang terdiri panel surya, beban listrik, baterai, dan konverter arus searah/DC telah dibuat dan divalidasi. Simulasi jaringan listrik arus searah skala mikro dilakukan berdasarkan studi kasus. Pada simulasi tersebut, variasi konfigurasi baterai dan algoritma manajemen baterai dilakukan untuk mengetahui pengaruhnya terhadap keseimbangan neraca daya, kestabilan tegangan bus, dan tingkat konsumsi listrik dari baterai.

Konfigurasi 1, 2, dan 3 grup baterai mampu menjaga keseimbangan neraca daya. Ketiga konfigurasi tersebut mampu menjaga kestabilan tegangan bus pada nilai $24 \mathrm{~V}$. Variasi konfigurasi grup baterai menyebabkan tingkat konsumsi baterai yang beragam. Konfigurasi 3 grup baterai memiliki tingkat konsumsi listrik lebih hemat $0,1 \%$ dibanding konfigurasi grup baterai yang lainnya.

Variasi algoritma manajemen baterai berpengaruh terhadap keseimbangan neraca daya jaringan listrik. Algoritma tanpa berbasis nilai SoC menunjukkan performa terbaik yakni selisih suplai dan kebutuhan listrik bernilai $0 \mathrm{~W}$.

Variasi algoritma manajemen baterai berpengaruh terhadap kestabilan tegangan bus jaringan listrik. Algoritma tanpa berbasis nilai $S o C$ dan algoritma berbasis 2 nilai SoC mampu menjaga kestabilan tegangan bus pada 
nilai $24 \mathrm{~V}$. Tegangan bus mengalami penurunan sebesar $0,18 \mathrm{~V}$ pada penggunaan algoritma berbasis 1 nilai $\mathrm{SoC}$.

Variasi algoritma manajemen baterai berpengaruh terhadap tingkat konsumsi listrik baterai. Algoritma tanpa berbasis nilai $\mathrm{SoC}$ dan algoritma berbasis 1 nilai $\mathrm{SoC}$ memiliki nilai rerata penurunan sebesar $0,19 \%$. Algoritma berbasis 2 nilai $S o C$ memiliki nilai rerata penurunan sebesar $0,37 \%$.

\section{DAFTAR PUSTAKA}

[1] A. T. Elsayed, A. A. Mohamed, dan O. A. Mohammed "DC microgrids and distribution systems: An overview". Electric Power Systems Research, 119:407-417, 2015.

[2] G. R. Athira dan V. R. Pandi. "Energy Management in Islanded DC Microgrid Using Fuzzy Controller to Improve Battery performance". IEEE International Conference on Technological Advancements in Power and Energy, hal. 0-5, 2017.

[3] Y. Ito, Y. Zhongqing and H. Akagi, "DC microgrid based distribution power generation system", IEEE the 4th International Power Electronics and Motion Control Conference (IPEMC), vol. 3, pp. 1740-1745, 2004.

[4] U. Sangpanich. "A Novel Method of Decentralized Battery Energy Management for Stand-Alone PV-Battery Systems". IEEE PES Asia-Pacific Power and Energy Engineering Conference (APPEEC), 2014.

[5] X. Liu. "The Proportional Current Control Strategy for Equalization Circuits of Series Battery Packs". International Conference on Electrical Machines and Systems, hal. 2018-2021, 2018.

[6] H. Kakigano, Y. Miura and T. Ise, "Configuration and control of a DC microgrid for residential houses", Proceedings of Transmission \& Distribution Conference \& Exposition: Asia and Pacific, pp. 1-4, 2009.

[7] K. N. C. Jayasena, D. K. J. S. Jayamaha, N. W. A. Lidula, dan A. D. Rajapakse. "SoC Based Multi-Mode Battery Energy Management System for DC Microgrids". Moratuwa Engineering Research Conference (MERCon), hal. 468-473, 2019.

[8] N. C. Sahoo, S. Mohapatro, dan M. K. Senapati. "A SoC Based Voltage Control Strategy for DC Microgrid”. IEEE Electrical Power and Energy Conference (EPEC), (1):185-190, 2020.

[9] L. Jing, S. Yanxia, W. Dinghui, dan Z. Zhipu. "A Control Strategy for Islanded DC Microgrid with Battery / Ultracapacitor Hybrid Energy Storage System". Chinese Control and Decision Conference (CCDC), (20130093110011):6810-6813, 2016.

[10] U. K. Das, K. S. Tey, M. Yamani, dan I. Idris. "Maximum Power Flow Management for Stand-alone PV Based Battery Charging System". International Conference on Power Electronics and ECCE Asia (ICPE 2019 - ECCE Asia), 2030(Cc):0-5, 2018.

[11] V. A. Nugroho, "Pengembangan Algoritma Manajemen Baterai untuk Pengendalian Sistem Penyimpanan Energi pada Jaringan Listrik Tipe DC Skala Mikro", Tugas Akhir, Universitas Gadjah Mada, 2020.

[12] 4DIAC IDE - IEC 61499 Compliant Development Environtment. Diakses dari https://www.eclipse.org /4diac/en_ide.php, 10 Oktober 2019
[13] J. H. Christensen, T.I. Strasser, A. Valentini, dan V. Vyatkin, The IEC 61499 Function Block Standard: Software Tools and Runtime Platforms, 2012.

[14] European Commision-Joint Research Centre. "Photovoltaic Geographical Information System", 7 Agustus 2020.

[15] R. R. Pearson. "Photovoltaic Power Converter Modeling in Modelica"., Master Tesis, National Distance Education University, 2017.

[16] S. Dhar, R Sridhar dan Varun Avasthy. Modeling and simulation of photovoltaic arrays modeling and simulation of photovoltaic arrays. 2015.

[17] Kyocera. "KC200GT PV Module Datasheet", 30 Mei 2020

[18] O. Tremblay dan L. Dessaint. "Experimental Validation of a Battery Dynamic Model for EV Applications". World Electric Vehicle Journal, 3:289-298, 2009.

[19] S. Holmes. "RMS Error", 10 Juli 2020.

[20] E. Dursun dan O. Kilic. "Comparative evaluation of different power management strategies of a stand-alone $\mathrm{PV} /$ Wind/PEMFC hybrid power system". International Journal of Electrical Power and Energy Systems, 34(1):81-89, 2012.

[21] G. Rizzoni. Fundamentals of Electrical Engineering. McGraw-Hill, New York, 1 edition, 2009.

[22] Panasonic. "HHR650D Battery Datasheet", 30 Mei 2020.

[23] M. Yasuda. "Lithium Ion Battery US26659 Datasheet", Product Presentation Sony Energy Devices, 16 Agustus 2020. 